\title{
KRONIKA
}

AGNIESZKA DZIEDZICZAK-FOLTYN

Uniwersytet Łódzki*

MARCIN FRONIA

Polska Akademia Nauk**

DOI: $10.26485 / \mathrm{PS} / 2017 / 66.2 / 11$

\section{CO SOCJOLOGIA I SOCJOLOGOWIE MOGA WNIEŚĆ DO STUDIÓW NAD PRZYSZŁOŚCIĄ? - komunikat $z$ debaty zorganizowanej w ramach XVI Ogólnopolskiego Zjazdu Socjologicznego w Szczecinie}

Intencją organizatorów debaty ${ }^{1}$ było zastanowienie się nad dotychczasowym dorobkiem i perspektywami studiów nad przyszłością w Polsce, zwłaszcza w naukach społecznych, a w ich ramach - socjologii. Polska socjologia rzadko bowiem sięga po narzędzia z zakresu myślenia prospektywnego, podczas gdy nauki społeczne w interesujący sposób wykorzystują potencjał tej perspektywy. Rozwijane w Stanach Zjednoczonych czy krajach skandynawskich tzw. future studies zyskują coraz większe zainteresowanie instytucji życia publicznego, od administracji rządowej po podmioty gospodarcze i instytucje naukowe otwarte na współpracę interdyscyplinarną. Rośnie znaczenie planowania strategicznego, gdyż myślenie o przyszłości staje się coraz ważniejszym kryterium podejmowania decyzji „tu i teraz”. Rośnie także zapotrzebowanie instytucjonalne na wiedzę dotyczącą tworzenia strategii rozwoju kraju, na umiejętność dostrzegania mega-

* Dr, Instytut Socjologii UŁ; e-mail: a.dziedziczak@uni.lodz.pl

** Mgr, Instytut Filozofii i Socjologii; e-mail: mfronia@css.edu.pl

1 Organizatorami debaty byli dr Agnieszka Dziedziczak-Foltyn (IS UŁ) oraz mgr Marcin Fronia (IFIS PAN). 
trendów podczas analizy polityk regionalnych, sektorowych oraz publicznych. Określone wizje przyszłości funkcjonują także z powodzeniem w dyskursach modernizacyjnych.

W polskich naukach społecznych znaczenie perspektywy prospektywnej częściej doceniają głównie ekonomiści, np. inicjatorzy Polskiego Forum Myśli Strategicznej [http://www.pte.pl/353_forum_mysli_strategicznej.html] czy grono entuzjastów zrzeszonych w powstałym w 2011 roku Polskim Towarzystwie Studiów nad Przyszłością [http://www.ptsp.pl/o-nas/]. Wśród instytucji naukowych tradycja refleksji prognostycznych i strategicznych, wyrosłych jeszcze z głośnych debat wokół Granic wzrostu Meadowsów, rozwijana jest od kilku dekad, m.in. w Komitecie Prognoz „Polska 2000 Plus” przy Prezydium PAN [http://www. prognozy.pan.pl/], istnieje także $\mathrm{w}$ dorobku środowiska angażującego się na przestrzeni lat w działalność Polskiego Towarzystwa Współpracy z Klubem Rzymskim. Jak dotąd nie udało jej się jednak mocniej zakorzenić w regularnej refleksji socjologicznej polskich badaczy, a takim forum, które wydaje się najpełniej oddawać stan owej cyrkulacji idei w środowisku polskich socjologów są zjazdy Polskiego Towarzystwa Socjologicznego. W związku z tym organizatorzy debaty pragnęli zwrócić uwagę socjologów, zorientowanych najczęściej na przeszłość i teraźniejszość, na potencjał analityczny, przydatny w refleksji socjologicznej, dotyczący kategorii związanych z myśleniem o przyszłości. W ten sposób chcieli reaktywować swego rodzaju tradycję socjologicznego myślenia o przyszłości, w którą wpisywał się Jan Szczepański, zwłaszcza swoją książką z 1989 r. Polska wobec wyzwań przyszłości. Pierwotny pomysł narodził się jako koncepcja grupy zjazdowej poświęconej przyszłości. Niestety stosunkowo krótki czas promowania grupy w ramach procedury zjazdowej (niespełna 2 miesiące) spowodował, że grupa nie powstała. Fakt niepowołania grupy to smutny obraz deficytu myślenia o przyszłości wśród socjologów, świadczący o pozostawaniu w tyle za ekonomistami (którzy jeden ze swoich kongresów - w 2013 roku - w całości poświęcili przyszłości). Tymczasem wyjątkowość tematyki, z którą chętnie mierzą się naukowcy w innych krajach (np. w wysoko rozwiniętych krajach nordyckich), mogłaby podnieść rangę socjologii wśród nauk społecznych.

Celem dyskusji podczas Ogólnopolskiego Zjazdu Polskiego Towarzystwa Socjologicznego ${ }^{2}$ było reaktywowanie w polskiej socjologii tradycji analitycznego i strategicznego myślenia o procesach modernizacyjnych w perspektywie dhugoterminowej. Propozycja ta nie ignoruje rzecz jasna ogromnego i niezwykle

2 Debata odbyła się w formule wydarzenia towarzyszącego w piątek $16.09 .2016 \mathrm{w}$ godzinach 13.30-15.00 na Wydziale Nauk Społecznych UG, ul. Bażyńskiego 4, Gdańsk Oliwa, w sali C 103. 
ważnego dorobku refleksji socjologicznej, obejmującej perspektywę historyczną $\mathrm{w}$ analizie procesów modernizacyjnych, proponuje jednak otwarcie się socjologii polskiej na poszukiwania analityczne w tym aspekcie rzeczywistości społecznej, którego jeszcze w pełni nie znamy. Nie oznacza to jednak, że nic o nim nie wiemy. Posługując się różnymi konfiguracjami określonych czynników, narzędzi i dostępnych danych, możemy budować potencjalne scenariusze. Ważne, aby debata o przyszłości nie była wyłącznie obszarem dominacji nauk ekonomicznych, wypowiadających się częstokroć o kwestiach znajdujących się w obrębie zainteresowań socjologów, jak choćby społeczne konsekwencje procesów technologicznych, ekonomicznych, środowiskowych, administracyjnych, demograficznych itd. Debatę z udziałem zaproszonych gości oraz publiczności prowadziła dr Agnieszka Dziedziczak-Foltyn (IS UŁ), natomiast w roli debatujących wystapili, w trzech panelach:

1) prof. Lech Zacher (Akademia im. L. Koźmińskiego) - „Konceptualizacja myślenia o przyszłości w naukach społecznych";

2) mgr Marcin Fronia (IFiS PAN) - „,(Nie)obecność myślenia o przyszłości w socjologii jako wyzwanie teoretyczne i praktyczne";

3) dr hab. Kazimierz Musiał (prof. UG i Södertörn University w Szwecji) - „Rola myślenia o przyszłości w generowaniu dobrobytu społecznego - lekcje dla Polski z krajów nordyckich".

Jako pierwszy głos zabrał w debacie Prof. Lech Zacher, który od lat zajmuje się refleksją nad przyszłością w ramach Komitetu Prognoz „Polska 2000 Plus” przy Prezydium PAN. Profesor zakreślił bardzo szerokie tło dla rozważań o przyszłości w naukach społecznych. Podkreślając wielokrotnie podczas swojego wystapienia rolę rewolucji techniczno-informacyjnej w kształtowaniu przyszłości, zaznaczył, że przyszłość buduje się dzisiaj poprzez jej przewidywanie i planowanie. Tymczasem w Polsce nie chcemy się tym zajmować naukowo, włączając się w procesy strategicznej dyskusji o wyzwaniach modernizacyjnych. Dlatego raport Michała Boniego „Polska 2030”, który w strukturach administracji publicznej rozpoczął niejako trend tworzenia strategii i analiz scenariuszowych, przeszedł bez większego echa w środowisku naukowym, niezauważony w debacie publicznej nawet jako pewien specyficzny fakt, do którego warto się odnieść, chociażby w sposób krytyczny. Zdaniem Lecha Zachera wynika to prawdopodobnie z upatrywania w zajmowaniu się przyszłością futurologii, która w warunkach PRL traktowana była jako nauka burżuazyjna czy wręcz paranauka. $Z$ drugiej strony w czasach PRL kwitła również myśl prognostyczna. Dziś jednak mamy do czynienia z wyraźnym deficytem naukowego i krytycznego rozważania możliwej/prawdopodobnej oraz 
pożądanej przyszłości. Nie chodzi tu jednakże o rozwijanie rozważań o charakterze życzeniowym, ale o opracowywanie pewnych modeli, trendów i scenariuszy przyszłości, które mogą być przydatne dla człowieka i instytucji (publicznych, pozarządowych, gospodarczych, a także ponadnarodowych), pełniąc funkcje mobilizacyjne, oświeceniowe czy ideologiczne i polityczne.

Drugi mówca, Marcin Fronia, socjolog reprezentujący Instytut Filozofii i Socjologii PAN (ale również zajmującą się krajami nordyckimi Fundację Naukową Norden Centrum ${ }^{3}$ ), wskazał na potrzebę socjologicznej perspektywy w zajmowaniu się przyszłością. Swoją wypowiedź rozpoczął od przywołania pojęcia rozumu strategicznego, które, jako kategoria przydatna do analizy różnorakich czynników, w tym zewnętrznych, również ułatwiałoby prognozowanie oraz socjologiczną analizę megatrendów. Marcin Fronia nawiązał przy tym do wspomnianego przez przedmówcę raportu ministra Boniego „Polska 2030”, oceniając pozytywnie sam fakt opracowania tego raportu, jednak krytycznie odnosząc się do nieuwzględnienia w nim perspektywy nauk społecznych. Socjolog podkreślił, że dyskurs o przyszłości w Polsce jest zdominowany przez ekonomistów, co sprawia-jego zdaniem - że fetyszyzowane są liczby, które czasami zaczarowują kwantyfikowane trendy, natomiast marginalizowane sa, a nawet nieobecne, czynniki wynikające z megatrendów społecznych, jak również społecznych konsekwencji analiz modernizacyjnych. Jako przykład uwzględnienia takich czynników Marcin Fronia podał analizę młodych naukowców na potrzeby raportu „Polska 2050” przygotowanego przez Komitet Prognoz [Fronia, Kafara, Kirejczyk, Prandecki (red.), Wawrzyński [2011], w której punktem wyjścia było założenie autorów, że „Polska nie jest samotną wyspą”, a analizy scenariuszowe powinny w możliwie najlepszy sposób uwzględniać zmieniające się konteksty społeczne. Dlatego bardzo trudno jest tworzyć czy odgórnie zakładać modele (jak model polaryzacyjno-dyfuzyjny ministra Boniego) bez pokazania dynamiki zmian czynników zewnętrznych, w tym czynników społecznych. Tego, zdaniem socjologa, zabrakło w raporcie „Polska 2030” . Uwzględnienie społecznych czynników byłoby również przydatne $\mathrm{w}$ analizie transformacji do zielonej gospodarki, będącej współcześnie istotnym trendem międzynarodowym, w Polsce traktowanym jednak $\mathrm{z}$ dużą rezerwą, często z powodu braku odpowiedniej wiedzy o potencjalnych skutkach tych procesów dla takich obszarów życia społecznego, jak rynek pracy,

W gronie międzynarodowych badaczy współpracujących z Norden Centrum są m.in. takie postacie jak prof. Joakim Palme, szwedzki socjolog, były dyrektor Sztokholmskiego Instytutu Studiów nad Przyszłością, syn Olofa Palme, socjaldemokratycznego premiera Szwecji, a także prof. Bernd Henningsen z Humboldt-Universität zu Berlin, jeden z inicjatorów interdyscyplinarnej współpracy w regionie Morza Bałtyckiego,. 
zdrowie publiczne, poziom innowacyjności, racjonalne gospodarowanie zasobami naturalnymi, jakość życia itd. O deficycie społecznej czy też socjologicznej perspektywy świadczą również zdominowane przez nauki techniczne konkursy grantowe programu Horyzont 2020 dotyczące obszaru pt. Wyzwania Społeczne (Social Challenges). Tymczasem nauki techniczne nie dysponują takimi narzędziami do badania społecznych skutków przemian technologicznych, jakie wykorzystuje socjologia. Konieczne jest jednak wyjście z cienia i pokazanie, jak duży jest potencjał analiz socjologicznych w interdyscyplinarnej współpracy z naukami technicznymi. Inny przytoczony przykład omawianego deficytu dotyczył obszaru zarządzania kryzysowego, który zdominowały psychologia i nauki o zarządzaniu. W swojej wypowiedzi na temat przyszłości Marcin Fronia zwrócił uwagę na kraje skandynawskie i USA, w których w imponujący sposób rozwijają się studia nad przyszłością. Stąd wzięła się koncepcja zrównoważonego rozwoju ${ }^{4}$, która mogła zrodzić się jedynie tam, gdzie powszechne jest planowanie, myślenie strategiczne i długoterminowe, umożliwiające przewidywanie społecznych, środowiskowych i ekonomicznych skutków zmian klimatycznych, np. prognozowanie związane z wyczerpywaniem się zasobów naturalnych oraz bezpieczeństwem energetycznym. Świadomość tych procesów miała następnie istotny wpływ na kierunek rozwoju innowacyjności w tych regionach świata. $\mathrm{Na}$ zakończenie prelegent podkreślił, że socjologowie (i socjologia jako dyscyplina) mogliby wnieść do studiów nad przyszłością takie wykorzystanie narzędzi swojej dyscypliny, które nie kojarzyłoby się ani z wulgarnym socjologicznym jasnowidztwem, ani „wróżeniem z fusów”, byłoby jednak oczekiwanym przez inne dyscypliny włączeniem się socjologii w analityczną refleksję o społecznych skutkach złożonych procesów modernizacyjnych. Częstokroć kierunek tym procesom nadają bowiem określone decyzje instytucjonalno-administracyjne, niejednokrotnie pozbawione świadomości lub dostępu do wiedzy na temat długoterminowych następstw bądź też po prostu możliwych, a czasem lepszych dla jakości życia społecznego, scenariuszy alternatywnych.

4 Zainicjowana pierwotnie przez norweską premier Gro Harlem Brundtland w 1987 roku, w raporcie na zlecenie ONZ pt. „Nasza wspólna przyszłość” (Our common future). Od tego czasu termin „zrównoważony rozwój” wszedł na stałe do słownika debaty publicznej, a nawet znalazł się jako jedno z obowiązkowych kryteriów horyzontalnych w realizacji programów finansowanych z funduszy unijnych we wszystkich krajach Unii Europejskich. Przez kolejne lata koncepcja zrównoważonego rozwoju ewoluowała, poddawana krytycznej dyskusji. Nie umniejsza to jednak jej znaczącego wpływu na refleksję o długoterminowym myśleniu o procesach modernizacyjnych, wykraczającym wyraźnie, co przyznają dziś sami ekonomiści, poza wąsko rozumiane indeksy wzrostu gospodarczego. 
Jako trzeci wystapił w debacie Kazimierz Musiał, blisko związany z socjologią skandynawista z Uniwersytetu Gdańskiego pracujący na Uniwersytecie Södertörn w Szwecji. Podkreślił on, że tym, co różni skandynawski punkt widzenia od polskiego, jest dużo większe docenienie przyszłości niż przeszłości w kontekście naukowego zajmowania się nimi przez nauki społeczne. Przeszłość można zostawić historykom, żeby odkodowali jej znaczenia, ale też przede wszystkim po to, aby służyła zrozumieniu i tworzeniu obecnego społeczeństwa. Na sukces społeczno-ekonomiczny krajów skandynawskich składa się m.in. bardzo silna instytucjonalizacja studiów nad przyszłością. W każdym kraju nordyckim funkcjonują instytuty badań nad przyszłością, które de facto (aczkolwiek i w oryginalnym nazewnictwie) reprezentują inny charakter future studies. Są one powoływane do badań nad przyszłością i jej planowaniem, czyli badają to, co ma być, a nie co będzie. Wyjaśniając rolę myślenia o przyszłości w generowaniu dobrobytu w Skandynawii, Kazimierz Musiał omówił jego uwarunkowania. Zwrócił uwagę m.in. na duże znaczenie celu ideologicznego, który przyświecał budowaniu nowego społeczeństwa, ale też myślenia strategicznego uzasadniającego sens zajmowania się przyszłością, np. na potrzeby inżynierii społecznej. W tym celu prelegent odwołał się do XIX-wiecznej historii, wskazując na tradycję studiów nad przyszłością w krajach skandynawskich wynikającą z negatywnych doświadczeń narodów na skraju przetrwania. 100 lat temu był to bowiem najbiedniejszy obszar Europy, z którego masowo emigrowano za ocean w celu poprawienia swych warunków życia czy w ogóle szans na przeżycie. Sytuacja społeczno-ekonomiczna w tamtym czasie doprowadziła do powoływania wielu komisji wspieranych przez rządy skandynawskie, które legitymizowane były przez merytokratycznie umocowanych ekspertów i polityków (reprezentujących różne opcje ideologiczne). Komisje te miały za zadanie opracowywanie dokładnych raportów dających możliwie obiektywny obraz danej kwestii społecznej wraz z zaleceniami, co należy zrobić, aby daną sytuację zmienić. Najbardziej spektakularną i paląca kwestią przełomu XIX i początku XX w. była masowa emigracja. W reakcji na tę sytuację w Szwecji powołano komisję ds. emigracji, prowadzono dyskusje, wydawano publikacje oraz formułowano zalecenia, których trafność można było pozytywnie zweryfikować po ponad dwudziestu latach ${ }^{5}$. Skuteczność opartej na szerokiej bazie eksperckiej wiedzy naukowej, prognozowanej i uzasadnionej w owych raportach, była tak ogromna, że od wczesnych lat międzywojennych

Pracująca w latach 1907-1913 oficjalna komisja Emigrationsutredningen przygotowała

20 tomów akt i danych statystycznych oraz 900 -stronicowy dokument podsumowujący wraz z zaleceniami działań na niwie politycznej i społecznej. 
racjonalne planowanie przyszłości stało się oczywistym składnikiem rodzącej się inżynierii społecznej ${ }^{6}$.

Podczas dyskusji, która nastapiła po zaplanowanych wypowiedziach uczestników debaty, najwięcej miejsca poświęcono doświadczeniom nordyckim. Pojawiły się pytania o rozwinięcie skandynawskich doświadczeń w zakresie socjologicznych badań nad przyszłością i modernizacją o konkretne obszary życia społecznego, w których te badania wykorzystywano następnie w praktyce (szkolnictwo wyższe, rozwój innowacyjności, zielona gospodarka, polityki publiczne). Zwrócono także uwagę na zbyt słabą, w porównaniu do innych krajów UE, a krajów skandynawskich w szczególności, współpracę polskiej nauki (w tym nauk społecznych) z gospodarką, co może być jednym z elementów traktowania przez nauki społeczne refleksji o przyszłości jako dziedziny, na którą i tak nie ma się wpływu. Podkreślono cenne odwołania do dziedzictwa polskiej myśli społecznej na temat wyzwań przyszłości, które domagało się rewitalizacji. Ze strony publiczności pojawiły się także propozycje dotyczące kontynuowania i rozwijania tego tematu w trakcie kolejnych Zjazdów PTS oraz innych wydarzeń o charakterze naukowym. Organizatorzy debaty liczą na to, że zainicjowane wydarzenie przyczyni się skutecznie do większego otwierania się polskiej socjologii na współpracę transdyscyplinarną i wykorzystywanie kategorii prospektywnych w pracach badawczych.

\section{BIBLIOGRAFIA}

Fronia Marcin, Agnieszka Kafara, Edward Kirejczyk, Konrad Pradecki (red.), Mirosław Wawrzyński. 2011. „Polska 2050 r. Wyzwania na drodze do przyspieszenia Przyszłość”. Świat-Europa-Polska 2. [online]

Szczepański Jan. 1989. Polska wobec wyzwań przyszłości. Warszawa: Uniwersytet Warszawski.

http://psep.czasopisma.pan.pl/images/data/psep/wydania/No_2_2011/03_Polska_2050.pdf. http://www.pte.pl/353_forum_mysli_strategicznej.html

http://www.ptsp.pl/o-nas/

http://www.prognozy.pan.pl/

6 Powiązanie racjonalności naukowej z badaniami na rzecz przyszłości było szczególnie ważne u zarania socjaldemokratycznego państwa opiekuńczego w Szwecji, czego ucieleśnieniem w 1934 r. była publikacja książki Gunnara i Alvy Myrdalów pt. Kryzys w kwestii ludnościowej. Zainicjowana wówczas dyskusja o ,profilaktyce społecznej” zaowocowała w kolejnych dziesięcioleciach zwróceniem większej uwagi na poprawę zdrowia publicznego, jako koniecznego elementu państwa opiekuńczego. 